\title{
Comparative, Similative and Simulative Expressions in Ese Ejja
}

\author{
Marine Vuillermet \\ Dynamique Du Langage - CNRS \& Université Lyon 2
}

This paper examines the expression of comparison in the Amazonian language Ese Ejja (Takanan) and explores both quantitative (relative (in)equality and superlativity) and qualitative comparison (similarity and simulation). This broad perspective reveals a clear asymmetry: while qualitative comparison is expressed via morphemes well incorporated into the grammar of the language, i.e. dedicated suffixes and enclitics, and is well represented in the corpus, quantitative comparison is most often expressed by strategies (rather than dedicated morphology) like clause juxtaposition and is scarce in my corpus of spontaneous language. The quasi-absence of dedicated morphology for the expression of quantitative comparison is all the more remarkable when taking into account that the language displays a large class of adjectives with a rich paradigm of adjectival affixes, which, for instance, negate, attenuate or question the adjectival root.

This paper describes the expression of comparison in the Amazonian language Ese Ejja (Takanan). Following Fuchs (2014), I distinguish quantitative from qualitative comparison. Quantitative comparison is understood as the comparison of two entities with regard to gradable properties, while qualitative comparison expresses a more general manner (dis)similarity between two entities. The constructions and strategies examined here express thus not only comparison of (in)equality, but also other kinds of comparison like similarity ('be like') or simulation ('do as if').

The perspective chosen resulted from two observations: while qualitative comparison is well attested in my natural corpus, quantitative comparison is infrequent and mostly illustrated with non-spontaneous data. Furthermore, a narrower perspective would have been reductive: Ese Ejja has one dedicated but rare morpheme for comparison of equality and no dedicated morphology for encoding inequality and superlativity. On the other hand, similative and simulative comparison are expressed with dedicated grammatical morphemes or constructions.

The paper is organized as follows: Section 1 offers relevant background on the language and its speakers. Section 2 is dedicated to the adjective morphology: Ese Ejja noticeably privileges predicative adjectives (a large class of bound roots associated to a variety of suffixes) over attributive ones (a small class with low functional load). Section 3 describes the expression of quantitative comparison. It first illustrates the diversity in conjoined comparative strategies, and then discusses the superlative strategy and the dedicated but rare equative degree morpheme. Section 4 focuses on the more frequent expression of qualitative comparison, encoded by two constructions for the expression of similarity and one for simulation. Section 5 summarizes the various pieces of evidence demonstrating the clear preference in this Amazonian language to express comparison qualitatively rather than quantitatively.

\section{The Ese Ejja and their language}

\subsection{Classification, vitality and methodology}

Ese Ejja (aka Ese'eja, Esse Ejja, Chama and Huarayo) is a language of the Takanan family, together with four other languages. According to Girard (1971), the five languages subdivide into 3 branches: the Chamik (Ese Ejja), the Kavinik (Cavineña) and the Takanik (Araona, Maropa/Reyesano and Tacana) branch. There is a well-established link between Takanan and 
Panoan languages, although it is not clear whether this is due to contact or genetic relatedness (see e.g. Fleck (2013: 22ff.), and also Valenzuela and Vuillermet (2016) for some evidence of contact).

About 1,700 Ese Ejja live in 9 communities settled along the Madre de Dios, Orthón and Beni rivers in the southwestern Amazon, in Bolivia and Peru. Approximately 1,500 Ese Ejja speak one of the two varieties, Madidi (Bolivia only) or Sonene (Bolivia and Peru) Ese Ejja. The Madidi variant is still transmitted and used on a daily basis in most villages, while the Sonene one is becoming less vital especially in Peru. The dominant Spanish language is also spoken by most Ese Ejja with various degrees of command (Vuillermet 2012: 58; 69ff.). Baawaja Ese Ejja is a third, more distinct variant; it is very occasionally spoken by a handful of elderly people.

Data for the present paper mostly represents the most vital Madidi dialect, and comes from a variety of sources. Original fieldwork in the Bolivian community of Portachuelo Bajo between 2005 and 2016 provided different types of data: spontaneous data (narratives and fieldwork notes re-checked with a consultant, noted $\{$ na $\}$ and $\{\mathrm{fi}\}$, respectively), semi spontaneous data elicited with visual stimuli like the Frog story by Mayer (1969), noted $\{$ Frog\}, and elicited data, noted $\{\mathrm{el}\}$. One example comes from Shoemaker \& Shoemaker's (1983) tagmemic sketch grammar, noted $\{\mathrm{sk}\}$. In addition, examples were extracted from the Bible (Riepma 2006), noted $\{\mathrm{bi}\}$, to compensate for the scarcity of natural data illustrating the quantitative comparison. ${ }^{1}$ By contrast, qualitative comparison is well attested in my natural corpus and mostly illustrated with spontaneous examples.

\subsection{Typological profile and relevant features}

Ese Ejja marks ergative alignment via ergative case marking $=(y \sim w) a$ and limited verb indexation, i.e. $-k a$ for $3^{\text {rd }}$ person Agent only, as example (1) illustrates. ${ }^{2}$

\section{(1) $\boldsymbol{E}$-sho'i=a e-na'ba mishi-ka-ani. \\ NPF-child=ERG NPF-mouth touch-3A-PRS \\ 'The child is touching his mouth.' $\{$ Frog $\}$}

Subjects of intransitive verbs and objects of transitive verbs take the (unmarked) absolutive case, as illustrated in example $(2 a)$ and $(2 b)$ respectively.

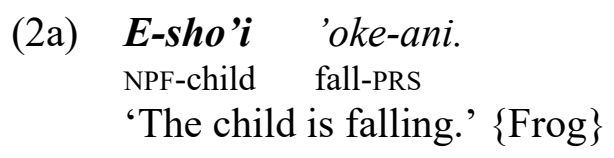

\footnotetext{
${ }^{1}$ I am very grateful to Lourens de Vries (Vrije Universiteit, Amsterdam). Thanks to the Paratext program, he helped me to extract examples from the Greek New Testament, in which adjectives have morphologically coded comparative and superlative forms. I was then able to go through the corresponding translations in the Ese Ejja Bible (Riepma 2006). As has been mentioned above, although more natural data would have been preferable, this data from the Bible is important, as it allows the filling of some gaps in the data.

${ }^{2}$ The following spelling conventions are used: $/ \mathrm{tg} /\langle\mathrm{ch}\rangle, / \mathrm{k}^{\mathrm{w}} /\langle\mathrm{kw}\rangle, / \mathrm{P} /\left\langle{ }^{\prime}\right\rangle, / \mathrm{b} /\left\langle{ }^{\prime} \mathrm{b}\right\rangle, / \mathrm{d} /\left|\left\langle{ }^{\prime} \mathrm{d}\right\rangle, / \mathrm{g} /\langle\mathrm{sh}\rangle,\right| \chi|<\mathrm{jj}\rangle, / \mathrm{h} /$ $<\mathrm{j}>, / \mathrm{n} /<\tilde{\mathrm{n}}>, \mathrm{j} /<\mathrm{y}>, / \mathrm{ej} /<\mathrm{ei}>, / \mathrm{ja} /<\mathrm{ia}>, / \mathrm{jo} /<\mathrm{io}>$. Abbreviations: ABS absolutive, ALL allative, COM comitative, COME.TRS\&DO come transitorily and do (the main verb action), CONT continuous, CTRS contrastive, DEM demonstrative, DEPR depreciative, DIM diminutive, DIST distal, ERG ergative, EXCL exclusive, EXS existential, EQU equative, FOC focus, FUT future, GEN genitive, GO.TO.DO go to do (the main verb action), INCL inclusive, INTS intensifier, IPFV imperfective, lit. literally, LOC locative, MAN.FOC manner focus, NEG negative, NMZnominalizer, NPF noun prefix, PAS past, PERL perlative, PL plural, POS positive adjectival suffix, PRIV privative, PROX proximative, PRS present, Q polar question particle, RDP reduplication, REL relativizer, REP reportative, RES resultative, RPAS remote past, SG singular, SIMIL similative, (Sp) Spanish loanword, SS Same subject, TEL telic, TMP temporal.
} 

Majoya
e-sho'i
jjasowa-ka-ani
yowa $=a$
peijepejje $=a$.
then
NPF-child frighten-3A-PRS
watchamacallit=ERG owl=ERG
'Then the, whatchamacallit, owl, frightens the child.' $\{$ Frog $\}$

Copula subjects behave like intransitive subjects as illustrated in (3).

\section{(3) E-sho'i kia-yeno=pishana ani. \\ NPF-child POS-sad=SOMEWHAT sit.PRS \\ 'The child is (lit. sits) a bit sad.' \{Frog $\}$}

Ese Ejja pronouns also follow an ergative alignment. Ese Ejja is a pro-drop language and pronouns are mostly used for emphasis. There are two main sets of pronouns: Set A are independent pronouns that appear in main clauses only, while Set B are bound pronouns that appear in subordinate clauses only. Two further minor sets (C and D) are defective paradigms and probably only appear in main clauses.

Constituent order is very flexible and pragmatically determined (compare SOV in (1) and OVS in (2b)). However, main clauses tend to be verb-final $(\mathrm{S}(\mathrm{O}) \mathrm{V}$, as illustrated in (1) and (2a)), and subordinate clauses are obligatorily verb-final. Possessors in NPs mostly precede their possessees but can sometimes be disjoined and follow them as in (8a).

The template of finite verbs displays fifteen slots, of which three are obligatorily filled: the root in Slot 0, the person indexation $-k a$ in Slot +6 (as in (1) and (2b)), and the tense/mood marker in Slots $-3,+8$ or +11 (e.g. the present marker -ani in (1) and (2a-b)). The only exception is the posture verbs, which remain unmarked for present, as illustrated in (3). ${ }^{3}$ The other optional slots include:

- lexical roots - incorporated nouns (Slot -1$)$, but also adjective (Slot $+1 / 2$ ) and verb roots (Slot $+1 / 2)$; note that the combination of two verb roots ${ }^{4}$ is only used for the expression of Path and Resultative, but not for the expression of comparison, as e.g. in Ewe (Ameka, 2015) and in many Meso-American languages (Stolz and Stolz 2001);

-adverb-like suffixes, e.g. the simulative suffix -nisho (Slot +3$)$ dealt with in Section 4.4; -associated motion suffixes (Slot $+5 / 7) ;^{5}$ note that, unlike in Nivacle (Fabre, this volume), none of them is used as a standard marker in the comparative construction;

-aspectual markers (Slot +10$)$.

Ese Ejja has two classes of adjectives, the attributive and the predicative class. The dozen attributives are suffixed bound roots that have a low functional load. They essentially appear in:

-lexicalized expressions like e-me- 'ai (NPF-hand-big) 'thumb' and e-me-sisi (NPF-hand-small) 'a finger other than thumb';

-Ese Ejja names like 'Dejja-'oshe (man-white) and Pona-'ao (woman-tall) - see Vuillermet (2012: 309-11);

\footnotetext{
${ }^{3}$ This absence of marking can be explained historically: the four present markers are grammaticalized posture verbs, see Vuillermet $(2009 ; 2012$ : ch. 14) for a detailed account of the omnipresence of the posture expression in Ese Ejja. ${ }^{4}$ They are called verb compounds, as the compounds are either made of a verb plus an adjective root, or of two verb roots. This latter subtype could be alternatively called serial verb constructions (SVCs), according to Durie's (1997) definition.

${ }^{5}$ Associated motion morphemes in Ese Ejja are mono- or bisyllabic verbal suffixes that associate motion to the main verb event. Typical semantics are 'do before leaving', 'do when arriving', 'do on your way (away)', 'do on your way back home', 'do here and there', 'go to do', 'come to do', etc.
} 
-definite entities like $e$-ki-sisi (NPF-house-small) 'the little house (in which we used to live, by contrast to the big house in which we now live)'.

Because the predicative class - the kia- adjective in particular - is the most relevant class for the present paper, its morphology and syntax are detailed in the next section (see also Vuillermet 2012: ch. 12).

\title{
2. Predicative adjectives
}

Predicative adjectives most often occur as copula complements. They consist of three subtypes of adjectives, namely (i) kia-adjectives, (ii) adjectives derived from verbs and nouns, and (iii) a handful of independent adjectives - only this last type is open to borrowings. The derived adjectives either consist of verb roots affixed by the positive prefix $e$ - RESULTATIVE or the negative suffix -jjima RESULTATIVE.NEGATIVE, or of noun roots affixed by the positive suffix -jji PROPRIETIVE or the negative suffix -má PRIVATIVE.

The kia-adjectives are typologically remarkable at the morpho-semantic and syntactic levels. This subclass consists of about 100 bound roots that require a prefix or a suffix to form an independent word. When adjectives are elicited, the citation form usually consists of the bound root plus the positive prefix kia-, after which kia-adjectives are named. The negative counterpart -'ama is also frequent in texts.

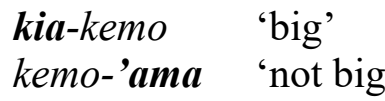
POSITIVE
NEGATIVE

Note that the positive adjectival prefix kia- Pos illustrated in (4a) appears to have some derivational properties in some restricted cases. For instance, the verb wishi- 'have a running nose' has an adjectival counterpart kia-wishi, which qualifies someone who always has a running nose. Another example comes from the Bible, where the noun mimishi 'sin' has an adjectival counterpart kiamimishi 'be a sinner'.

The four affixes given in (5) are infrequent.

$\begin{array}{lll}\text { (5a) iye-kemo } & \text { 'not so big, almost big' } \\ \text { (5b) } & \text { ache-kemo } & \text { 'how big? (!)' } \\ \text { (5c) } & \text { kemo-(a)jja } & \text { 'as big' } \\ \text { (5d) } & \text { ma-kemo } & \text { 'that big' }\end{array}$

\author{
SLIGHTLY \\ INTERROGATIVE (and also exclamative) ${ }^{6}$ \\ EQUATIVE \\ DEMONSTRATIVE
}

The morpheme iye- in (5a) would be best translated by 'slightly, quasi, not so, almost'. It mostly appears in the expression of comparison, as discussed in Section 3.1 below. The morpheme achein (5b) has a corresponding interrogative (pro)noun ache 'which'. The equative suffix -(a)jja in (5c) so far only appears spontaneously with wiso- 'many', and is discussed in Section 3.3 below. The demonstrative prefix $m a$ - in (5d) seems to be felicitous with dimension, position and quantification adjectives only. It has a corresponding independent distal demonstrative ma, like in ma esho' $i$ 'that child'. The next section shows that four affixes (positive, negative, 'slightly', and equative) play a role in the expression of quantitative comparison, often in combination with the modifiers - nee VERY or =pishana SOMEWHAT.

${ }^{6}$ Called "superlativo" in Riepma (2012: 3), examplified as ache-pame-nee 'tan bueno es', literally 'so good it is'. Intonation does play a role in the exclamative interpretation, but it is unclear whether the presence of the suffix -nee 'very' is obligatory or not. 
All Takanan languages have a large class of predicative adjectives with bound roots very comparable to the Ese Ejja kia- adjectives (see Guillaume 2008: 68; 369ff. for Cavineña; Emkow 2006: 390; 411 for Araona; Guillaume 2012: 211-12 for Maropa; Guillaume 2014: 19-20 for Tacana). Nevertheless, the bound predicative adjectives in the sister languages combine with fewer affixes than in Ese Ejja. Furthermore, the positive affixes are not cognates: Cavineña and Tacana have a suffix - $d a$, Maropa a suffix -me, while Araona and Ese Ejja have a prefix a- and kia-, respectively. On the other hand, the negative suffix in Ese Ejja - 'ama is very plausibly cognate with the negative affix -dama in Cavineña. ${ }^{7}$ Guillaume (2008: 374) suggests an origin in the combination of the positive suffix - $d a$ and a negative morpheme - $m a$. Ese Ejja, Araona and Maropa have thus probably renewed their positive adjectival affixes.

The kia-adjectives cover most of the semantic classes distinguished by Dixon (2004: 3-5): dimension, value, color, physical properties/qualification, position, speed, quantification and difficulty. The nine classes are illustrated in (6a-g).

\begin{tabular}{|c|c|c|c|c|c|}
\hline (6a) & DIMENSION & $\begin{array}{l}\text {-'ao } \\
\text { 'tall' }\end{array}$ & $\begin{array}{l}\text {-'beje } \\
\text { 'thin' }\end{array}$ & $\begin{array}{l}\text {-'biso } \\
\text { 'small' }\end{array}$ & $\begin{array}{l}\text {-'dwe } \\
\text { 'deep' }\end{array}$ \\
\hline$(6 b)$ & VALUE & $\begin{array}{l}\text {-'bame } \\
\text { 'beautiful' }\end{array}$ & $\begin{array}{l}\text {-'boti } \\
\text { 'pleasant' }\end{array}$ & $\begin{array}{l}\text {-kamaja } \\
\text { 'tiring, costly' }\end{array}$ & $\begin{array}{l}\text {-mase } \\
\text { 'mad' }\end{array}$ \\
\hline$(6 c)$ & COLOR & $\begin{array}{l}\text {-'oshe } \\
\text { 'white' }\end{array}$ & $\begin{array}{l}\text {-tawa } \\
\text { 'green' }\end{array}$ & $\begin{array}{l}\text {-tewe } \\
\text { 'black' }\end{array}$ & $\begin{array}{l}-w o ' o \\
\text { 'red' }\end{array}$ \\
\hline$(6 d)$ & PHYSICAL PROPERTY & $\begin{array}{l}\text {-'bikia } \\
\text { 'sweet' }\end{array}$ & $\begin{array}{l}\text {-'bikie } \\
\text { 'heavy' }\end{array}$ & $\begin{array}{l}\text {-'iwi } \\
\text { 'smelly' }\end{array}$ & $\begin{array}{l}\text {-jeyo } \\
\text { 'slippery' }\end{array}$ \\
\hline$(6 e)$ & HUMAN PROPENSITY & $\begin{array}{l}\text {-ajjajja } \\
\text { 'frightened' }\end{array}$ & $\begin{array}{l}\text {-'bei } \\
\text { 'happy' }\end{array}$ & $\begin{array}{l}\text {-'bicho } \\
\text { 'ashamed' }\end{array}$ & $\begin{array}{l}\text {-sheshe } \\
\text { 'whimsical' }\end{array}$ \\
\hline$(6 \mathrm{f})$ & Position / SPEEd / QuANTIFICATION & $\begin{array}{l}\text {-chipi } \\
\text { 'near' }\end{array}$ & $\begin{array}{l}\text {-wesha } \\
\text { 'remote' }\end{array}$ & $\begin{array}{l}\text {-shono } \\
\text { 'late' }\end{array}$ & $\begin{array}{l}\text {-wiso } \\
\text { 'numerous' }\end{array}$ \\
\hline$(6 g)$ & DIFFICULTY & $\begin{array}{l}\text {-kewa } \\
\text { 'complex, hidden' }\end{array}$ & $\begin{array}{l}\text {-taa } \\
\text { 'unclear' }\end{array}$ & & \\
\hline
\end{tabular}

Only SIMILARITY and AGE are encoded by other means, the enclitic =jayojja (see Section 4.1) and the two nouns $e$-sho ' $i$ 'NPF-child' and $e$-tii 'NPF-old.person' respectively. ${ }^{8}$

Syntactically, kia-adjectives are mostly used predicatively as copula complements. As copula clauses are the clause type found in the comparative strategy (Section 3.1), they are described in detail now.

Five copulas are available: the neutral copula $p o-\sim p w a-$ 'be', and the four posture verbs ani'sit', neki- 'stand', jaa- 'lie', 'ba'e- 'float, hang', as illustrated in (7a-b) below (see also (3) above).

(7a) With the neutral copula $p w a-$ 'be'

$\begin{array}{llll}\text { Ekwana kia-ajjajja-nee } \sim \text { nee } & \text { pwa-ani } & \text { ekwikia=jo. } \\ \text { 1EXCL.ABS } & \text { POS-scared-very RDP } & \text { be-PRS } & \text { devil_spirit=LOC } \\ \text { 'We are very scared of the devil spirit.' }\{\text { na }\} & \end{array}$

${ }^{7}$ Cavineña /d/ and Ese Ejja /dg/ (realized /?/ within words) are reflexes of the same proto-phoneme.

${ }^{8} \boldsymbol{e}$-tii (RES-grow) can alternatively be analyzed as a resultative adjective derived from the verb tii- 'grow'. I chose to analyze it as a noun because it is more frequently used as a noun (i.e. heading NPs, and marked with nominal morphology like cases or plural) than as a resultative adjective (in copula complement). Last, the alternative analysis is not available for the antonym $e$-sho' $i$ 'child'. 
(7b) With the posture verb ani- 'sit'

$\begin{array}{llll}\text { Ekwana jjeya kia-'biwi ani } & o=j o . \\ \text { 1EXCL.ABS now POS-glad sit.PRS } & 3=\text { LOC } \\ \text { 'Now we are happy about her.' }\{\text { na }\} & \end{array}$

The posture verbs refer to the actual position of the copula subject or to the cultural position associated with it, which is related to the gender or shape of the positioned entity (see Vuillermet 2009; Vuillermet 2012: ch. 14 for a detailed description of the system and its use). The copula is often unexpressed, especially in the present tense. This is illustrated in (8) below.

A very productive way to modify a noun with such a predicative adjective is to incorporate it into the adjective (Vuillermet 2014): it derives a compound comparable to the (not as productive) English adjectival compound blue-eyed or narrow-minded. With such an incorporation, the entity modified is still the possessee, but the copula subject is the semantic possessor. The following pair of examples contrasts ewa'o 'tail' as subject of the predicate kiapoji 'bald' in (8a) and as an incorporated noun into the same predicate in $(8 \mathrm{~b})$.

POSSESSEE POSSESSOR (GEN)

$\begin{array}{lll}\text { E-wa'o } & \text { kia-poji } & \text { 'do }=j a . \\ \text { NPF-tail } & \text { POS-bald } & \text { red.howler=GEN }\end{array}$

'The tail of the red howler (monkey sp.) is bald.' $\{\mathrm{na}\}$

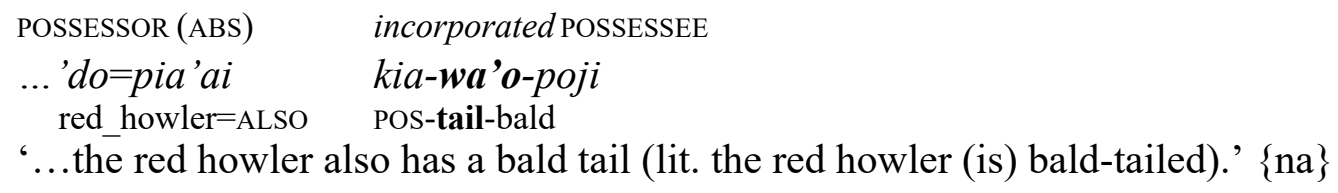

Incorporation into adjectives is a general device to increase the semantic valency of an adjective: in (9), the incorporated (pro)noun is no longer a possessed entity, but the scary entity.

\section{(9) Kia-mi-ajja, kia-marina-ajja, \\ POS-2SG.ABS-scared POS-Marina-scared}

'She is scared of you, she is scared of Marine.' $\{\mathrm{fi}\}$

As will be discussed later in Section 3.3, incorporation (of the standard) is also relevant in equative clauses.

Predicative adjectives are also used:

-as adverbs - kiawesha pokinaje 'he went far away', sa'ajjakanaje kiawiso 'he searched a lot';

-as the second element of verb compounds to form depictive secondary predicates (with no affix) kiyo-'biso-naje (heat.up-little-PAs) '(the water) evaporated';

-(less frequently) in nominal function - kiawiso =a (ERG) mei iñakanaje 'Many (people) grabbed stones'.

The expression of comparison in Ese Ejja is very different from the straightforward, dedicated constructions à la European languages, where the lexical (comparee-standard-parameter) and grammatical (standard and parameter markers) elements are easy to locate. Section 3 explains the difficulties in describing quantitative comparison in Ese Ejja. The following factors complicate the 
description of comparison: first, the dedicated morphology, whenever existent, is infrequent. Second, if the comparison strategies used correspond to well-attested strategies crosslinguistically, they are also very infrequent, and rarely translated as such. On the other hand, Section 4 will later show that qualitative comparison is pervasive in the grammar and displays a number of strategies, all well integrated into the grammar.

\section{Quantitative comparison}

\subsection{The comparative strategies}

Ese Ejja does not have dedicated comparative morphemes but juxtaposes clauses expressing opposite properties, as exemplified in (10).

$\begin{array}{llll}\text { (10) } & \text { Eya } & \text { kia-'biso, miya } & \text { kia-kemo! } \\ \text { 1SG.ABS } & \text { Pos-small } & \text { 2SG.ABS } & \text { POS-big } \\ \text { 'I (am) smaller than you (are) } & (\text { lit. I (am) small, you (are) big).' }\{\mathrm{el}\}\end{array}$

Such periphrastic comparison expressions have been called conjoined comparative constructions (Stassen 1985: 44), polarity comparative type (Stolz and Stolz 2001), or comparative strategies (Type S) (Dixon 2008: 802). I will use the term "conjoined comparative strategy" (a mix of Stassen's and Dixon's terminology) because 1) it is transparent ("conjoined" refers to the clause juxtaposition), and 2) it highlights that this is a biclausal "strategy" rather than a "dedicated construction". In his sample of 167 languages, Stassen (2013) catalogues 20\% (34 languages) with such a strategy, all located in the Americas, Papunesia ${ }^{9}$ or Australia.

In example (10), the two juxtaposed clauses are copula clauses. Each one consists of:

-a subject - the comparee and the standard are the copula subject of their respective predicate; - a predicate-here a pair of antonymic adjectives.

As mentioned earlier, copulas are often left unexpressed in copula clauses. The juxtaposed clauses in the comparative strategies are no exception, as illustrated in (10) and (11). Only example (13) has an overt copula, the posture verb ani- 'sit', marked by the existential.

The contrast of properties is expressed by either a pair of antonymous predicates as in (11), a positive-negative pair as in (12), or a positive-'slightly' pair as in (13). Each pattern is illustrated in turn. ${ }^{10}$ The antonymous predicate pair can consist of kia-adjectives as in (10) or nouns as in (11).

Antonymous predicates

Pico e-tii, Macario e-sho'i.

P. NPF-old_person M. NPF-child

'Pico is older than Macario (lit. Pico is an old person, Macario is a child).' $\{\mathrm{fi}\}$

\footnotetext{
${ }^{9}$ The glossary of glottolog.org (consulted on July 10th, 2016) defines Papunesia as a macro-area covering the islands between Sumatra and the Americas, excluding islands off Australia and excluding Japan and islands to the North of it. The relevance of Papunesia as a relevant macro-area is discussed in Hammarström and Donohue (2014), and has been adopted in the World Atlas of Languages Structures online (Dryer and Haspelmath 2013).

${ }^{10}$ Stassen (2013) illustrates different patterns with different languages, although several patterns often seem to be available in one language (see e.g. Bochnak \& Bogal-Allbritten (2015)).
} 
In (11), the two children are less than 10 years old and are both considered children (esho' $i$ ). The noun etii 'old person' is thus not used as a norm but as a relative standard contrasting with esho' $i$ 'child'. Whether this construction is consistently not norm-related remains to be investigated (see Bierwisch 1989 and the concluding discussion in the present section).

Example (12) displays a positive-negative adjective pair, i.e. the same root takes the positive prefix in the first clause and the negative suffix in the second (plus the modifier =pishana 'somewhat, a bit').

(12) Positive vs. (lessened) Negative

\section{'Bishe=jje kia-kamaja, motone=jje kamaja-'ama=pishana.} canoe=PERL POS-tiring motorboat=PERL costly-PRIV=SOMEWHAT

'It is more tiring to go by canoe than by motorboat (lit. it is tiring by canoe, it is somewhat not tiring by motorboat).' $\{$ na $\}$

Example (13) displays a positive-'slightly' pair, i.e. the same root takes the positive prefix (plus the intensifier -nee nee 'very RDP') in the first clause, and the prefix SLIGHTLY in the second.

(13) (intensified) Positive vs. Slightly

'Beka kia-kemo-nee nee peyo y-ani, 'beka iye-kemo. some POS-big-very RDP snake EXs-sit some SLIGHTLY-big 'There exist some snakes that are bigger than others (lit. there sit some very big snakes, some not so big).' $\{$ na $\}$

The predicates in each of the two clauses may be modified: in (14), the positive predicate is intensified with -nee 'very', and the negative predicate is attenuated with =pishana 'somewhat'.

(intensified) Positive \& (lessened) Negative

$\begin{array}{cllll}\text { 'Beka } & \text { kia-se-nee-nee, } & \text { ojaya } & \text { meneno } & \text { kia-nee-nee } \\ \text { some } & \text { Pos-tooth-painful-very } & 3 \mathrm{GEN} & \text { poison(Sp) } & \text { Pos-painful-very }\end{array}$

'Some are very poisonous (lit. are teeth-painful), their poison is very painful,

\begin{tabular}{|c|c|c|}
\hline & $\begin{array}{l}\text { meneno } \\
\text { poison }(\mathrm{Sp})\end{array}$ & $\begin{array}{l}\text { nee-'ama=pishana. } \\
\text { painful-PRIV=SOMEWHAT }\end{array}$ \\
\hline
\end{tabular}

the poison of others is less painful (lit. is somewhat painless).' $\{$ na $\}$

Finally, example (15) displays three sentences contrasting '(exactly) here' and '(slightly) further (away)'. The comparee 'here' (oya=tii and then $m a=n e i=y a)$ is intensified with $=t i i$ INTs and $=n e i$ INTS; the standard is first encoded by the bound adjective root -wesha 'far' mitigated by the prefix iye- SLIGHTLY, and then repeated with a reduplication of the root iye-wesha-wesha.

(15a) 'Beka=a chofer=kwaa=se oya=tii nekia-'okia-ka-ñaki-ani,

some $=$ ERG driver(Sp)=PL.ERG=1INCL.ABS 3ABS=INTS put_up-put_down-3A-COME.TRS\&DO-PRS

ma, gazolina sho-ka-ani=jo.

$\mathrm{DEM} / \mathrm{REL}$ gazoil(Sp) pour-3A-PRS=LOC

'Some drivers leave us (lit. put us down, standing) exactly where they pour gasoline.' $\{$ na $\}$ 


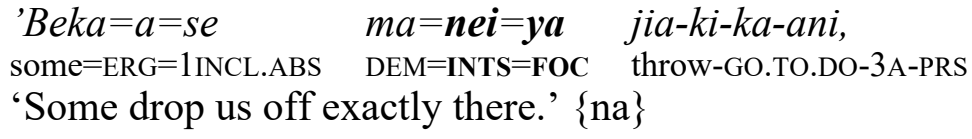

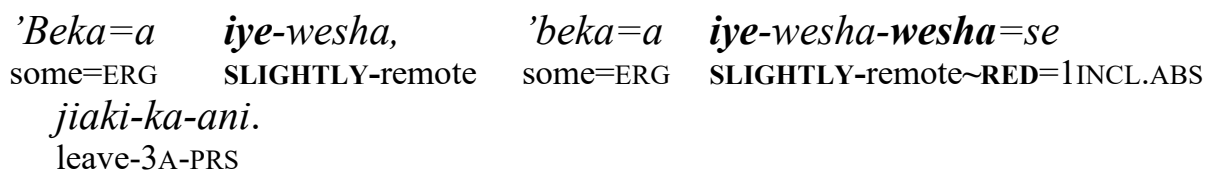

'Some leave us somewhat further, some still a bit further (but we still have to go to the market by foot or by motorboat).' \{na\}

The reduplication of the adjective root is another productive process to modulate the intensity of a property. The consultant considers iye-wesha wesha (SLIGHTLY-remote $\sim$ RED) to be equivalent to kia-wesha=pishana (POS-remote=SOMEWHAT) 'somewhat far': the reduplication further attenuates the adjective value, already mitigated by the prefix iye- sLightLY. The morphological device has been tested with other adjective roots encoding dimension, value, human propensity or quantification, like iye-'ao 'ao (SLIGHTLY-tall RED), iye-'bame 'bame (SLIGHTLY-beautiful RED), iyekene kene (SLIGHTLY-angry RED), iye-wiso wiso (SLIGHTLY-many RED).

The conditioning factors for the distribution of the three conjoined comparative patterns (antonymous, positive-negative and positive-sLightLy pairs) and the use of modifiers require further research. The two concepts discussed by Bochnak \& Bogal-Allbritten (2015), namely NORMRELATEDNESS and CRISP JUDGEMENT, may prove relevant.

A construction is NORM-RELATED if it entails that the bare (or positive) form of the adjective holds. In English, ' $\mathrm{X}$ is as tall as $\mathrm{Y}$ ' is not norm-related: $\mathrm{X}$ and $\mathrm{Y}$ need not be tall and may actually be small. By contrast, ' $\mathrm{X}$ is as small as $\mathrm{Y}$ ' is norm-related: $\mathrm{X}$ and $\mathrm{Y}$ must both be small. In Washo (isolate (Hokan?), California), the conjoined comparative strategy is norm-related with both predicates 'tall' and 'small'. We saw in (11) that the first entity was old compared to the other one, but not old per se. The construction contrasting antonymous predicates is thus probably not normrelated in Ese Ejja, at least not with the pair 'young/old'. Other antonymic pairs and, of course, the two other strategies (the positive-negative and positive-slightLY pairs) need to be tested in the future.

Note that the interrogative and the demonstrative constructions, ache-kemo (INT-big) 'how big' and ma-kemo (DEM-big) 'that big' are also not norm-related. One can talk about how thin one's flip-flop has become using ma-moo (DEM-thick), not *ma-beje (DEM-thin).

CRISP JUDGEMENT contexts are those in which the two entities being compared differ minimally along the relevant dimension (Kennedy 2007a; 2007b). In English, in a context where X is only very slightly taller than $\mathrm{Y}, X$ is taller than $Y$ is felicitous, while compared to $X, Y$ is tall is not. Bochnak \& Bogal-Allbritten (2015) show that, in such contexts, Washo speakers use two distinct adjectives (not very big vs. slightly fat) rather than a positive vs. negative one (big vs. not big), i.e. following Stassen's (2013) terminology, the antonymic strategy (big vs. small) rather than the positive-negative polarity strategy (big vs. not big). Bochnak \& Bogal-Allbritten's (2015) actually emphasize the necessity to share common ground with the speakers over the entities discussed and suggest fieldwork methods to overcome elicitation issues. The relevance of crisp judgement contexts may prove promising to explain the distribution of the variants available for the conjoined comparative strategy in Ese Ejja.

Note that the five examples provided above are the only spontaneous examples in my corpus: this comparative strategy is rarely used, quantitative comparison is rarely expressed. With regard to the sister languages, none of the descriptions so far available mention the comparison of 
inequality (Guillaume 2008 for Cavineña; Pitman 1980 and Emkow 2006 for Araona; Guillaume 2012 for Maropa; Guillaume 2014 for Takana). This void certainly indicates a similar infrequency of the expression of comparison in the sister languages.

Dixon (2008: 813) observes that "many languages that have been in contact with Spanish have borrowed its [i]ndex of [c]omparison más 'more' - but not, as a rule, menos 'less'." Ese Ejja data seems to confirm his observation: menos is not attested in my corpus, while the borrowing of más appears three times. It occurs only in two similar contexts where the speaker wants to specify a site 'further downriver'.

$$
\begin{aligned}
& \begin{array}{llll}
\text { más } & \text { allacito, } & \text { más, } & \text { makwa=wasijje=pishana } \\
\text { more(Sp) } & \text { there.DIM } & \text { more(Sp) } & \text { downriver=ALL=SOMEWHAT }
\end{array} \\
& \text { iya-ka-'io-naje. } \\
& \text { take_onboard-3A-TEL-PAS }
\end{aligned}
$$

\begin{tabular}{|c|c|c|c|c|c|}
\hline $\begin{array}{l}\text { Como } \\
\text { LIKE(Sp) }\end{array}$ & $\begin{array}{l}\text { 'ba'eñ } a-a=k w a n a \\
\text { arrive-RPAS=PL }\end{array}$ & $\begin{array}{l}p w a ́ \\
\text { RPAS }\end{array}$ & $\begin{array}{l}\text { yowa'ba'a, } \\
\text { whatchamacallit }\end{array}$ & $\begin{array}{l}\text { más } \\
\text { more }(\mathrm{Sp})\end{array}$ & $\begin{array}{l}\text { abajo } \\
\text { down }(\mathrm{Sp})\end{array}$ \\
\hline $\begin{array}{l}\text { no, } \\
\text { right }(\mathrm{S}\end{array}$ & p) $\begin{array}{l}\text { makwa }=\text { wasijje } \\
\text { downriver }=\mathrm{ALL}\end{array}$ & & & & \\
\hline
\end{tabular}

'And then more there, a bit more downriver, he took us on board.' $\{$ na $\}$

A third spontaneous occurrence, together with many other borrowings, appears in a sentence where people are advised to learn more. Note that más 'more' always occurs together with adjectives expressed in Spanish. This borrowing is probably only incipient.

\subsection{The superlative strategy}

The expression of superlativity being altogether absent from my corpus, I had to look for examples in the Bible to illustrate the strategy used in Ese Ejja. Example (17) shows that the (here reduplicated) intensifier -nee 'very' can also function as a superlative marker.

(17) Jikio 'beka e-sowi kia-pame-nee $\sim$ nee.

DEM some NPF-story POS-good-very RDP

'There is no other commandment greater than these (lit. these few words are very very good).' \{bi, Mark 12:31.2\}

The reduplication of the intensifier is very frequent (65 occurrences in my corpus) but does not systematically have a superlative function, as illustrated in the following example from the Frog Story.

On the other hand, example (19) shows that the intensifier does not need to be reduplicated. In this second example from the Bible, the standard of comparison is introduced by pia... jama pojjiama 'like no other X (lit. other... like not)'. According to Gorshenin's (2012: 107) typology, the 
strategy of negative predication to encode the standard corresponds to Type A/Neg, a subtype of the most widespread encoding (Type A).

$\begin{array}{clll}\text { Majoya } & \text { kijje powa-'io-majje } & \text { kia-kemo-nee } & \text { tii-poki-ani } \\ \text { then } & \text { after sprout_off-TEL-TMPSS POS-big-very } & \text { grow-CONT-PRS } \\ \text { pia } & \text { e-'bana=kwana jama=pojjiama. } & \\ \text { other } & \text { RES-SOw=PL } & \text { so=NEG_PHRASE }\end{array}$

'(When it is sown), it grows up, becomes the greatest of all garden plants (lit. then once it has sprouted, it'll keep growing very big, it is not like other (things) sown).' \{bi, Mark $4: 32\}$

The use of an intensifier to express superlativity seems to also be available in the sister language Cavineña. According to Guillaume (pc, June 9, 2015), the basic sense of ebiasu is 'very, a lot', but example (20) is best translated with a superlative.

$$
\begin{aligned}
& \text { Ema ebiasu tuche-da. } \\
& \text { 1SG a_lot strong-ASF } \\
& \text { 'I am the strongest.' (Guillaume 2015) }
\end{aligned}
$$

The absence of dedicated morphology to express superlativity as well as the absence of spontaneous examples highlight that such a concept is uncommon for Ese Ejja speakers.

\subsection{The equative degree morpheme $-(a) j j a$}

While the language has no dedicated comparative constructions to express relative or absolute inequality, it has a (very infrequent) dedicated equative degree morpheme: the adjectival suffix -(a)jja 'as'. ${ }^{11}$ Note that no similar morpheme has been described for the sister languages. Following Haspelmath and Buchholz (1998: 281), this synthetic suffix should be called an equative degree morpheme. This section discusses the few examples available and a plausible origin involving manner semantics.

For the sake of clarity, the first examples discussed come from an elicitation session where two consultants were repeating made-up sentences and commenting on them in a lively discussion in Ese Ejja. In (21), the comparee is the zero-marked absolutive subject of the adjectival predicate kemojja 'as big', the copula is absent, and the standard is incorporated into the predicate.

\section{(21) 'Bawapoji Miguel-kemo-jja. \\ Alejandro Miguel-big-EQU \\ 'Alejandro is as tall as Miguel.' $\{\mathrm{el}\}$}

Incorporation is more obvious when it occurs between a prefix and the adjectival root as in (8b). However, the incorporation of the standard in the equative construction is proven by 1) the presence of a single primary stress for the whole word (Miguél-kemo-jja in (21)), 2) the obligatorily reduced form of the pronoun illustrated in (22), and 3) the apparent fixed order of the standard with respect to the parameter. Indeed, the consultants were jokingly comparing the size

\footnotetext{
${ }^{11}$ Note that I cannot account for the variation between -jja and -ajja - the latter form is attested in the examples from the Bible (no associated recordings) and in recorded data from 2005 (see wiso-ajja in (24b-25), where the additional vowel /a/ can be heard though it is not very loud), but was clearly rejected by my consultants in 2016, and corrected without /a/, wiso-jja. When talking generally, I will thus refer to the form -(a)jja.
} 
of various people, producing several equative sentences, in which the comparee would move around, as Maca in (23), but not the standard 'Bawapoji.

(22a)

O-kemo-jja.

3ABS-big-EQU

'He is as tall as (you).' $\{\mathrm{el}\}$ (22b)

*Oya kemo-jja.

3ABS big-EQU

Intended: 'He is as tall as (you).' $\{\mathrm{el}\}$ (but OK if intended: 'They are equally tall.')
'Bawapoji-kemo-jja
Maca! Oya
kemo-jja $=y a$.
Alejandro-big-EQU
Maca(rio) 3ABS big-EQU $=\mathrm{FOC}$

'(Context: I had just stated that Macario, the son of one of the consultants, was now about my size, the consultant specified that his son Maca had (rather) reached the size of the other consultant, Alejandro:) He is as tall as Alejandro, Maca! They are equally tall.' \{fi\}

The equative degree -(a)jja plays two syntactic roles: first, it enables the bound adjectival root kemo 'tall' to form an independent predicate (like the other adjectival affixes listed in (4) and (5)). Second, and more importantly, it enables the adjective to have a second (incorporated) semantic argument.

The two spontaneous examples in (24) and (25) are complex for different reasons. In (24), many elements are dropped, so that the (morpho)syntactic description of the construction remains tentative. The comparee is unexpressed in (24b) but is expected to occur in the absolutive as in (24a) and in any regular copula clause. The predicate consists of (i) two incorporated elements the standard jikio 'DEM' and the noun año 'year (in Spanish) - (ii) the bound adjectival root -wiso 'many', and (iii) the equative degree -(a)jja. The copula is unexpressed.

PARAMETER COMPAREE

Ache-shekiaja-wiso mikie=shiye?

HOW-year-many 2SG.GEN=fiancé

'How old is your fiancé?'

STANDARD PARAMETER

Jikio-año-wiso-ajja $=y$ a.

DEM.PROX-year(Sp)-many-EQU=FOC

'(He is) as old as this (guy) (lit. (he is) this one many-yeared).' $\{\mathrm{fi}\}$

In (25), the comparee 'children' and standard 'banana' cannot both be objects of the verb 'dawaña 'I grill'. One has thus to consider a separate existential clause left implicit, of which the standard is the subject - cf. the English translation.

$\begin{array}{lllll}\text { STANDARD } & \text { PARAMETER-PARAMETER MARKER } & \text { COMPAREE } & \\ \text { E-'bakwa } & \text { wiso-ajja } \text { ekwaa 'dawa-aña } & \text { ejjawi } & \text { e-kemi-jji. } \\ \text { NPF-child(ABS) } & \text { many-EQU 1EXCL.ERG grill-PRS } & \text { banana(ABS) NMZ-go_with-NMZ } \\ \text { 'I grill as many bananas to go with (the food) as (there are) children.' }\{\text { na }\end{array}$

Haspelmath and Buchholz (1998: 298ff.) note that many European languages have special parameter markers and/or standard markers in constructions expressing quantity, like autant 'as much' in French. Although the only parameter spontaneously attested with the equative degree marker -(a)jja is -wiso 'many', other parameters available in elicitation are dimension (cf. kemo'big' in (21-23)), position, value, and human propensity, all illustrated in (26a-c). 


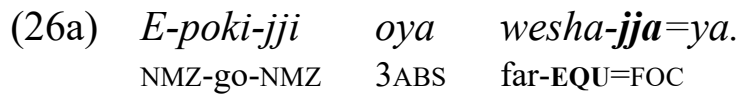

'To go (to Riberalta), they (Genechiquía and Villanueva) are equally distant.' $\{\mathrm{el}\}$

(26b) Oja='bakwa-'bei-(a)jja=ya oja=chii.

$3 \mathrm{GEN}=$ child-happy-EQU $=$ FOC $\quad 3 \mathrm{GEN}=$ father

'His father is as happy as his child.' $\{\mathrm{el}\}$

(26c) Oya oja=na-kojja-'bame-jja $=y a=k a$ !

$3 \mathrm{ABS} \quad 3 \mathrm{GEN}=$ mother-eye-beautiful-EQU $=\mathrm{FOC}=\mathrm{CTRS}$

'No, rather, she is as beautiful as her mother (lit. as her-mother-beautifully-eyed)!' $\{\mathrm{el}\}$

Although no clear origin is retrievable, it is interesting to note the similarity between $-(a) j j a$ and the ending of two words involving manner semantics, the adverb jikiajja 'in this way, like this' and the question word achajja 'how, in which manner'. The manner adverb comes from the demonstrative jikio DEM plus the suffix -ajja (jikiajja < jikio DEM.PROX + -ajja), and the question word from the interrogative word ache 'which' (or the interrogative adjectival prefix ache-) associated with the same suffix -ajja (achajja < ache 'which' + -ajja). ${ }^{12}$ They are illustrated in (27) and (28) respectively.

$\begin{array}{lllll}\text { E-yamajjana=jo } & \text { wana-sowa-ka-jji } & \text { jikiajja, } & \text { pia } & \text { jikiajja } \\ \text { NPF-beam=LOC } & \text { lay-go/put_up-EXT.OBL-EXT.OBL } & \text { so.PROx } & \text { other } & \text { so.PROx }\end{array}$

'One has to lay (it) up on the beam this way, and the other one this way.' $\{\mathrm{sk}\}$

\section{...e-'ba-jji achajja etiikiana 'ba'e-ka-a=pwa. \\ NMZ-know-NMZ how ancestors float-3S.PL-RPAS=RPAS}

'(I will tell this story) in order to know how (our) ancestors used to live.' \{na\}

Section 3 has shown that, despite the rich adjectival morphology of the language presented in Section 2, the expression of quantitative comparison is rare in Ese Ejja, and that it may even be rarer in the sister languages. Interestingly, the only dedicated quantitative marker - the equative degree marker -(a)jja attested in Ese Ejja only - is plausibly historically related to qualitative comparison (see Chamoreau \& Treis (forthcoming) for other languages across the world with a single morpheme or construction used for both equative comparison and similarity). The next section shows that the expression of qualitative comparison is much better represented in the corpus and thus probably less marked for the speakers.

\section{Qualitative comparison}

Ese Ejja has two similative devices. They compare two entities or events and highlight their (dis)similarities. They differ in their form (enclitic morpheme and multiword construction), and in their syntactic and discourse scope: the enclitic morpheme can compare two (dis)similar entities or events, and the multiword construction two events only. They are described in Sections 4.1 and

\footnotetext{
${ }^{12}$ This reconstruction actually supports a fuller form of the equative degree morpheme -ajja.
} 
4.2, respectively. The last subsection 4.3 discusses the simulative morpheme -nisho 'fake $\mathrm{V}$, do as if $\mathrm{V}^{\prime}$.

\subsection{The similarity enclitic =jayojja 'LIKE'}

The first similative morpheme discussed is very frequent. It is a phrasal enclitic that attaches either to the standard of comparison with which the comparee shares some similarity (behavior or property) (29)-(30) or to the property itself (31). In examples (29a-b), =jayojja marks two nouns. The enclitic can mark an intransitive (absolutive) subject as in (29a), or a transitive (ergative) subject as in (29b). The comparison highlights how doves and chickens move and scratch in a similar way.

(29a) Kachina=jayojja poki-ani. hen $(\mathrm{Sp})=$ LIKE $\quad$ go-PRS '(doves) walk like hens.' $\{$ na

(29b) Kachina $=a=$ jayojja kishishea-ka-ani. hen $(\mathrm{Sp})=$ ERG $=$ LIKE $\quad$ scratch-3A-PRS '(doves) scratch (the ground) like hens.' $\{$ na $\}$

In (29a-b), standards and comparees seem to occur in the same syntactic slot, as shown by the ergative case in (b). ${ }^{13}$ This is different from what happens in many SAE languages where the adverbial clauses used to such goals often have ambiguous readings: for instance, 'A beats B like C' can mean 'A beats B like A beats C' or 'A beats B like C beats B'. In Ese Ejja, because the enclitic =jayojja attaches directly to case marked nouns, a possible ambiguity between two possible standard phrases is ruled out. However, the same kind of ambiguity may appear, because the comparee itself may be left unexpressed. It is then only the context that specifies what exactly serves as the comparee.

In (30), the enclitic =jayojja attaches to two independent pronouns. The two compared entities have the same age.

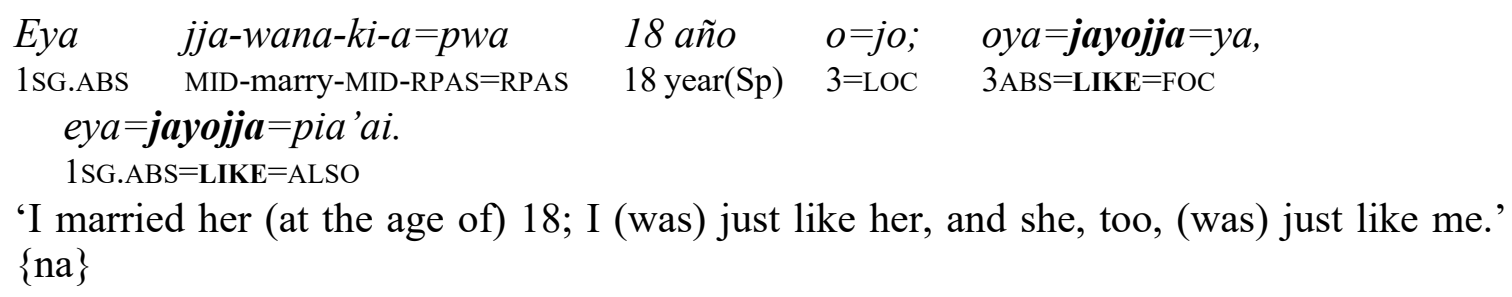

In (31), =jayojja attaches to a resultative adjective derived from a compound verb. This adjective is the predicate. The tail of the opossum looks like "something which has been peeled" (but it is naturally so).

$$
\begin{array}{ll}
\text { E-wa'o } & e-k w i a-p o j i=j a y o j j a \\
\text { NPF-tail } & \text { RES-hit-bald=LIKE }
\end{array}
$$

'His tail looks like (it has been) peeled (lit. like hit-bald).' $\{\text { na }\}^{14}$

\footnotetext{
${ }^{13}$ I thank Yvonne Treis for pointing this out to me.

${ }^{14}$ The speaker of this utterance is blind, so that 'feels like' would be even more appropriate.
} 
As highlighted above, the enclitic nature of =jayojja allows speakers to be very specific about the standard: it most frequently attaches to NPs but can also attach to predicates as in (31). The next example shows that it can also attach to clauses: in (32), =jayojja marks a finite clause as a standard. The speaker has enumerated the names of a few traditional dances and now details one of them, in which dancers imitate people going upriver by canoe. Note the presence in the main clause of the infrequent manner focus suffix -me, which requires an element expressing manner (here, the enclitic =jayojja). ${ }^{15}$

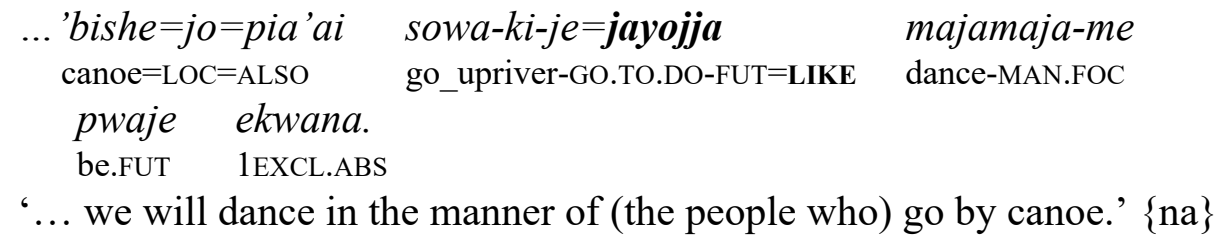

The phrase to which =jayojja is encliticized is often double-marked and introduced by the Spanish equivalent como 'like'. The next examples (33a-d) show that como 'like' equally introduces finite clauses (a-b) and NPs (c-d).

$\begin{array}{llll}\text { Como } & \text { kachina }=a & \text { ijjia-ka-ani=jayojja } & a-k a-a n i . \\ \text { LIKE(Sp) } & \text { hen }(\mathrm{Sp})=\text { ERG } & \text { eat-3A-PRS=LIKE } & \text { do-3A-PRS }\end{array}$

'Like the hens eat, so they do.' $\{$ na $\}$

\begin{tabular}{|c|c|c|c|}
\hline $\begin{array}{l}\text { 'Bewijaja } \\
\text { sloth }\end{array}$ & $\begin{array}{l}\text { eya }=j o \\
\text { heaven }=\text { LOC }\end{array}$ & $\begin{array}{l}\text { sowa-ki-ani } \\
\text { go_up-GO-TO_DO-PRS }\end{array}$ & $\begin{array}{l}\text { como } \\
\text { LIKE(Sp) }\end{array}$ \\
\hline $\begin{array}{l}\text { sowa-k } \\
\text { go up-G }\end{array}$ & $\begin{array}{l}\text { ani=jayojja. } \\
\text { TO.DO-PRS }=\mathbf{L I}\end{array}$ & & \\
\hline
\end{tabular}

$$
\begin{array}{llll}
\text { Como } & \text { ese }=a=\text { jayojja } & \text { poso, } & \text { no? } \\
\text { LIKE(Sp) } & 1 \mathrm{INCL}=\mathrm{ERG}=\text { LIKE } & \text { think_wrongly } & \operatorname{right}(\mathrm{Sp})
\end{array}
$$

'(The children think that the devil exists.) Like we wrongly think, right?' $\{$ na

(33d) Como yowa'ba'a... Iman=jayojja...

LIKE(Sp) whatchamacallit Iman=LIKE

'Like what's her name again... Iman... (her phantom is very strong).' $\{$ na $\}$

Note that such a combination was only uttered by three women aged from 30 to 60 , never by my older male consultant. It reminds one of the second similarity construction described in the next subsection 4.2.

Phrases encliticized by $=$ jayojja can be negated with the phrasal negator $=$ pojjiama ${ }^{16}$

\footnotetext{
${ }^{15}$ The focus marker -me triggers the use of an auxiliary (pwaje in example (32)). The function of -me is still obscure; it only appears elsewhere with jama 'so.PROX'. See Vuillermet (2012: 391) for more examples, and Guillaume (2008: 338ff.) for the description of a similar morpheme in the sister language Cavineña.

${ }^{16}$ The status of this phrasal negation remains to be clarified. It is phonologically independent (stress on the second

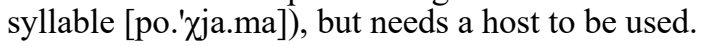


Pojjiaso=jayojja=pojjiama, oya kia-kima-nee-nee. fire_ant.sp=LIKE=NEG_PHRASE 3 ABS $\quad$ POS-prickle-painful-very 'It is not like pojjiaso (ant sp.), its prickle (of the fire ant) really hurts (no es como ese hormiga negro, su pulga (de hormiga de palo diablo) duele).' \{na\} or: 'Prickles of fire ants are more painful than those of other ants. (Esa hormiga de Palo diablo pica más fuerte que otro hormiga su puga).'

Note that the Spanish translation offered by the second consultant involves a quantitative comparison pica más fuerte '(lit.) stings more strongly than'. The (negated) similative marker may thus also take part in quantitative expression (here antonymous juxtaposed clauses).

The phrasal enclitic cannot be parsed, but one can note the ending in -jja, which points to a similar 'manner' origin as the equative adjectival suffix -(a)jja 'as' discussed in the previous subsection 3.3. The high frequency of the phrasal enclitic =jayojja supports the fact that qualitative expression of comparison is more relevant to the Ese Ejja grammar.

\subsection{Clausal similarity construction ma-ekwa $\sim$ jikio-ekwa ... jama $\sim$ kiajjaya (pojjiama)}

This construction allows the comparison of two situations, encoded in two parallel, often juxtaposed, clauses. A first finite clause introduces the standard situation, followed by, in most cases, the comparee situation, expressed in another finite clause. This biclausal construction consists of several, discontinuous morphemes:

-jikio-ekwa (DEM.PRoX-SIMIL) (or also ma-ekwa (DEM.DIST-SIMIL) in examples from the Bible) introduces the standard clause. This bimorphemic marker consists of a demonstrative plus the unknown morpheme ekwa. ${ }^{17}$

-kiajja(=ya) ('so.Prox') or jama(=ya) ('so.DIST') close the standard clause. They are deictic manner pronouns, but their status as phonologically independent morphemes in this specific construction requires further investigation, as they seem to require the focus marker $=y a$ or the negation marker = pojjiama to occur. The specific distribution of kiajja(ya) and jama(ya) is so far still unclear.

$$
\begin{aligned}
& \begin{array}{l}
\text { 'Beka=kwana, etiikiana } \\
\text { some }=\mathrm{PL}
\end{array} \\
& \text { ancestors }=j a=c h i i \\
& 1 \mathrm{INCL}=\mathrm{GEN}=\text { father }
\end{aligned}
$$

'Some of them, our ancestors, our fathers, they had two wives.'

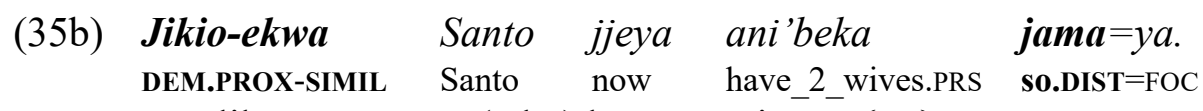

Just like Santo now (who) has two wives.' $\{$ na $\}$

The phrasal negation is the last element when the construction expresses dissimilarity, as in (36b). Just like phrases or clauses marked with the similative enclitic =jayojja, clauses marked with these discontinuous morphemes can also be introduced by como 'like (in Spanish)', being then 'triplemarked'.

\footnotetext{
${ }^{17}$ It may be cognate with the relativizer $k w a$.
} 
$\begin{array}{llllll}\text { (36a) } & \text { Bueno, } & \text { kia-pame eya } & \text { o=nijje } & \text { 'ba'e-poki-naje, } & \text { kia-'biwi-nee. } \\ \text { well(Sp) } & \text { POS-good } & \text { 1SG.ABS } & 3=\mathrm{COM} & \text { float-CONT-PAS } & \text { POS-glad-very }\end{array}$

(36b) Como jikio-ekwa jjeya tii=kwana jama=pojjiama. LIKE(Sp) DEM.PROX-SIMIL now grow=PL SO.DIST=NEG_PHRASE

'Well, I used to live (lit. float) well with her, happily. Not like today's adults (lit. the grown(-ups)).' $\{$ na $\}$

The two sentences seem independent for the following reasons. They often have the falling intonation characteristic of independent clauses (they end in a very low pitch, see Vuillermet (2012: 210)), and long pauses may occur between both clauses. Furthermore, Set A pronouns (for independent clauses only) are attested in examples from the Bible (not exemplified here because of their complexity). ${ }^{18}$ It is difficult to say if the verb in the standard clause is fully finite, as the examples (35b) and (37) contain posture verbs (unmarked for present) and as the verb in (36b) is left implicit. It is also difficult to assess if the verb is obligatorily final: in (35), it is final but I have not tested the constituent flexibility; in (37) the verb is the only constituent. On the other hand, both clauses are syntactically and semantically very tightly linked to each other: they seem to always have the same verb, which may even be omitted like in (36b).

The standard clause can be embedded in the comparee clause, as illustrated in (37): the sloth woman used to live in the forest, but her husband, who was polygamous (cf. example (35)), did not live with her in the forest but with his other wife in a house, like today's Ese Ejja.

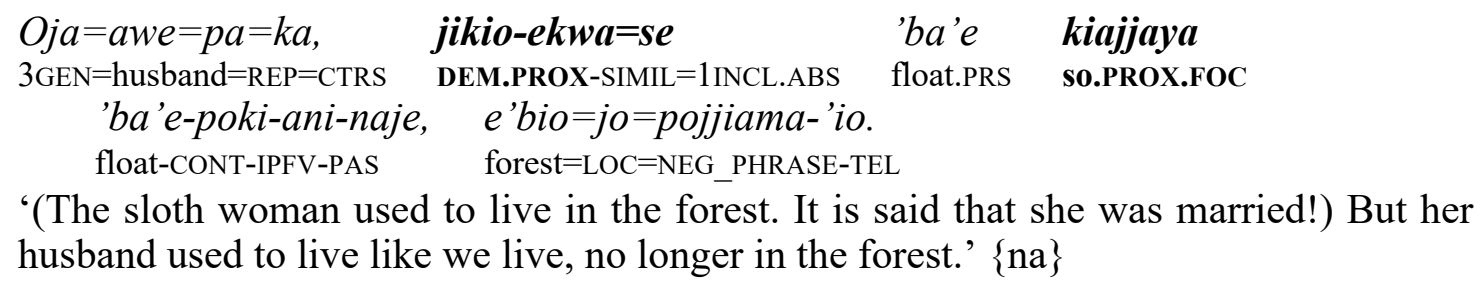

'(The sloth woman used to live in the forest. It is said that she was married!) But her husband used to live like we live, no longer in the forest.' $\{$ na $\}$

The clausal similarity construction seems to be falling into disuse, as only my older consultant (70 years old) uttered them. Note that in (36b), he starts the sentence with the Spanish como 'like' which precedes jikio-ekwa. As discussed earlier in Section 4.1, other slightly younger (and female) consultants use como... =jayojja (see examples (33a-b) to compare similar situations), maybe instead of the construction described in the present subsection. One can however still put forward the parallelism in the morpheme discontinuity of the two constructions como... =jayojja and jikioekwa... jama kiajjaya.

\subsection{The simulative -nisho}

The simulative is one of the non-obligatory verbal suffixes mentioned in Section 2. It enters Slot +3 , before the valency-changing morphology $($ Slot +4$)$ and the person indexation $($ Slot +6$)$. The Slot +3 position is thus still fairly close to the verb root and welcomes morphemes that modify the meaning of the event. The verbal suffix -nisho specifies that an entity pretends to carry out an action but he does not perform it for real (Vuillermet 2012: 495-96). The best translation for the

${ }^{18}$ Note that a Set C pronoun appears in example (37), and Set C pronouns are so far only attested in independent clauses. 
simulative is 'pretend/fake doing $\mathrm{X}$ ' or 'do as if'. This morpheme still has a strong link to comparison as it is about imitating a way of doing something. The most frequent examples involve children playing, as in (38a), or a person who wants to mislead someone: the context suggested for (38b) was that A will hide in his house so that B will think that A has gone. A would thus tidy up his house, properly close the door, etc.

(38a) Kekwa-nisho-ka-naje.

pierce-FAKE-3A-PAS

'They played war / They fake shooting (each other).' $\{$ fi $\}$

(38b) Poki-nisho-je.

go-FAKE-FUT

'He will fake going.' $\{\mathrm{el}\}$

(38c) Kawi-nisho-jaa.

sleep-FAKE-lie/PRS

'She fakes sleeping (lying).' $\{$ fi $\}$

(38d) Pa-nisho-naje.

cry-FAKE-PAS

'He fakes crying.' $\{\mathrm{fi}\}$

In some cases, it has a more lexicalized meaning: kia-nisho- (give-FAKE) means 'cheat' and miminisho- (speak-FAKE) 'lie'. Depending on the context, the literal sense 'pretend to give (and finally keep it)' or 'mouth (v), fake speaking' is probably also available in an adequate context.

The homophone attributive adjective -nisho occurs with nouns and pronouns - oya-nisho (3ABS-FAKE) 'a fake 'he/him', 'basha-nisho 'fake spider', etc. Names of toys are often derived with this adjective.

A more complex construction still involving the root -nisho plus the nominalization of the verb (and an auxiliary to bear the tense/mood suffix) encodes the avertive (Kuteva 2000), as illustrated by (39a-b): against the will of the agent, the action by the agent does not take place. (Note that Ese Ejja has still another morpheme called 'frustative' to encode actions whose goal is not reached.)

E-poki-jji-nisho kwa-naje.

NMZ-go-NMZ-FAKE be-PAS

'He wanted to go (but for some reason he could not).' $\{\mathrm{fi}\}$
$\begin{array}{ll}\text { Chok } a=a=p a & y \text {-awe } \\ \text { Choka }=\text { ERG=REP } & \text { NPF-husband }\end{array}$
e-kwia-wejja-jia-jji-nisho
a-ka-naje
'Choka almost clubbed her husband.' \{na\}

This section has shown that qualitative comparison in Ese Ejja prevails over quantitative comparison in at least two respects: the only morpheme dedicated to the expression of quantitative comparison (the equative suffix - $(a) j j a$ ) is outnumbered by the three morphemes and constructions dedicated to the expression of qualitative constructions (the enclitic =jayojja, the construction jikio/ma-ekwa... jama/jikiajja (pojjiama), and the suffix -nisho), and examples illustrating qualitative comparison are by far more frequent. 


\section{Conclusions}

This paper has highlighted that Ese Ejja has one main class of adjectives and a rich array of adjectival affixes; however, only one of these affixes is a dedicated morpheme that expresses equative comparison.

There is no dedicated morphology for comparison of inequality, despite the rich adjectival morphology described in Section 2. Ese Ejja uses the conjoined comparative strategy to express comparison of (in)equality, and actually offers a range of patterns: the two entities or properties compared can be encoded via antonyms and positive-negative pairs (or positive-sLIGHTLY) pairs, as is probably also the case in most languages displaying the conjoined strategy (see also the three types of conjoined strategies in the contribution by Özsoy \& Kaşıkara on Turkish Sign Language in this volume). Future research focusing on the distribution of the variants is required to better understand the semantic properties of adjectives in relation to the constructions they appear in.

Finally, this study intended to emphasize the importance of including the qualitative expression of comparison into the description of a language like Ese Ejja (see Rose (forthcoming) for a similar observation about Mojeño Trinitario (Arawak)): both the scarcity of dedicated morphology and of relevant spontaneous examples stress that quantitative comparison, perhaps except for the equative construction, has little relevance for the Ese Ejja grammar. By contrast, qualitative comparison is very well integrated into the grammar via three grammaticalized morphemes or constructions. While a broader perspective on comparison including qualitative expression is probably all the more crucial in languages with infrequent quantitative expression, it is certainly always of interest.

\section{References}

Ameka, Felix K. 2015. Surpassing exceed comparatives: On (in)equality comparative constructions in Ewe. Paper presented at the Workshop Comparative and Superlative Constructions: Typology and Diachrony. Amsterdam, Vrije Universiteit, 16-17 June 2015.

Bierwisch, Manfred. 1989. 'The semantics of gradation.' In Dimensional Adjectives: Grammatical Structure and Conceptual Interpretation, edited by Manfred Bierwisch and Ewald Lang, 71-261. Berlin: Springer-Verlag.

Bochnak, M. Ryan and Elizabeth Bogal-Allbritten. 2015. 'Investigating gradable predicates, comparison, and degree constructions in under-represented languages.' In Methodologies in Semantic Fieldwork, edited by M. Ryan Bochnak and Lisa Matthewson, 110-34. Oxford, New York: Oxford University Press.

Chamoreau, Claudine and Yvonne Treis. Forthcoming. Comparaisons d'égalité et de similitude et expression de la simulation. Special issue of Faits de Langue.

Dixon, R.M.W. 2004. Adjective Classes in Typological Perspective. Oxford: Oxford University Press.

- 2008. 'Comparative constructions: A cross-linguistic typology.' Studies in Language 32 (4): 787-817. doi:10.1075/s1.32.4.02dix.

Dryer, Matthew S. and Martin Haspelmath, eds. 2013. WALS Online. Leipzig: Max Planck Institute for Evolutionary Anthropology. http://wals.info/.

Durie, Mark. 1997. 'Grammatical structures in verb serialization.' In Complex Predicates, edited by A. Alsina, J. Bresnan, and P. Sells, 289-354. Stanford: CSLI.

Emkow, Carola. 2006. A Grammar of Araona, an Amazonian Language of Northwestern Bolivia. PhD diss., La Trobe University.

Fabre, Alain. This volume. 'Some peculiarities of comparative constructions in Nivacle (Mataguayo family, Paraguayan Chaco).' 
Fleck, David W. 2013. Panoan Languages and Linguistics. New York: American Museum of Natural History.

Fuchs, Catherine. 2014. La comparaison et son expression en français. Paris: Ophrys.

Girard, Victor. 1971. Proto-Takanan Phonology. Berkeley, Los Angeles, London: University of California Press.

Gorshenin, Maksym 2012. 'The crosslinguistics of the superlative.' In: Neues aus der Bremer Linguistikwerkstatt: Aktuelle Themen und Projekte 31, edited by Cornelia Stroh, 55-160. Bochum: Brockmeyer.

Guillaume, Antoine. 2008. A Grammar of Cavineña. Berlin, New York: Mouton de Gruyter.

—. 2012. 'Maropa (Reyesano).' In Las Lenguas de Bolivia, edited by Mily Crevels and Peter Muysken, 191-229. La Paz: Plural Editores. . 2014. El Idioma Takana. Esbozo de Su Fonología Y Su Gramática.

- 2015. 'Maintenance, loss and renewal of ergative marking in core argument pro-nouns in Takanan languages (Amazonian Bolivia and Peru).' Paper presented at the International workshop Diachronic Morphosyntax in South American Languages (28-30 May), DDLISH, Lyon, France.

Hammarström, Harald and Mark Donohue. 2014. 'Some principles on the use of macro-areas in typological comparison.' Language Dynamics and Change 4 (1): 167-87. doi:10.1163/22105832-00401001.

Haspelmath, Martin and Oda Buchholz. 1998. 'Equative and similative constructions in the languages of Europe.' In Adverbial Constructions in the Languages of Europe, edited by Johan van der Auwera and Dónall Ó Baoill, 277-334. Berlin, New York: Walter de Gruyter.

Kennedy, Christopher. 2007a. 'Modes of comparison.' In Proceedings of CLS 43, edited by Malcolm Elliott, James Kirby, Osamu Sawada, Eleni Staraki, and Suwon Yoon. Chicago: Chicago Linguistic Society.

- 2007b. 'Vagueness and grammar. The semantics of relative and absolute gradable adjectives.' Linguistics and Philosophy 30 (1): 1-45.

Kuteva, Tania. 2000. 'TAM-auxiliation and the avertive category in Northeast Europe.' In Areal Grammaticalization and Cognitive Semantics: The Finnic and Sami Languages, edited by Jocelyne Fernandez-Vest, 27-41. Tallinn, Paris: Eesti Keele Sihtasutus, Fondation de la Langue Estonienne.

Mayer, Mercer. 1969. Frog, Where Are You? New York: Dial Books.

Özsoy, Sumru A. and Hüner Kaşıkara. This volume. 'Comparatives in Turkish Sign Language (TID).'

Pitman, Donald. 1980. Bosquejo de La Gramática Araona. Notas Lingüísticas de Bolivia 9. Riberalta, Bolivia: Instituto Lingüístico de Verano en colaboración con el Ministerio de Educación y Cultura, Dirección Nacional de Antropología.

Riepma, Michael. 2006. Eyacuiñajija Esohui -- Nuevo Testamento Ese Ejja. Bolivia: Misión Nuevas Tribus.

—. 2012. Diccionario Ese Ejja - Castellano Castellano - Ese Ejja. Bolivia: Misión Nuevas Tribus.

Rose, Françoise. Forthcoming. 'Similar but different: the functions of the Mojeño Trinitario root expressing similarity.' In Comparaison d'égalité et de similitude et expression de la simulation. Special issue of Faits de Langues 51, edited by Claudine Chamoreau and Yvonne Treis. 
Shoemaker, Jack and Nola Shoemaker. 1983. El Discurso En El Idioma Ese Ejja. Relaciones Comunicacionales En La Gramática Ese Ejja. La Paz: Instituto Nacional de Estudios Lingüísticos, ILV.

Stassen, Leon. 1985. Comparison and Universal Grammar. Oxford, New York: Blackwell.

- 2013. 'Comparative constructions.' In The World Atlas of Language Structures Online, edited by Matthew S. Dryer and Martin Haspelmath. Leipzig: Max Planck Institute for Evolutionary Anthropology. http://wals.info/chapter/121.

Stolz, Christel and Thomas Stolz. 2001. 'Hispanicised comparative constructions in indigenous languages of Austronesia and the Americas.' In Lo Propio Y Lo Ajeno En Las Lenguas Austronésicas Y Amerindias. Procesos Interculturales En El Contacto de Lenguas Indígenas Con El Español En El Pacífico E Hispanoamérica, edited by Klaus Zimmermann and Thomas Stolz, Iberoamericana, 35-56. Frankfurt a.M: Iberoamericana Vervuert.

Valenzuela, Pilar M. and Marine Vuillermet. 2016. 'Non-canonical switch-reference and language contact in Western Amazonia.' Paper presented at the Syntax of the World's Languages, México City, México, August 192016.

Vuillermet, Marine. 2009. 'Los verbos de postura Ese Ejja no se quedan inmóviles. Y a veces se desvían.' In Conference on Indigenous Languages of Latin America-IV. Austin, Texas: http://www.ailla.utexas.org/site/cilla4/Vuillermet_CILLA_IV.pdf. . 2012. A Grammar of Ese Ejja, a Takanan Language of the Bolivian Amazon. PhD Diss., Université Lumière Lyon 2.

. 2014. 'Two types of incorporation in Ese Ejja (Takanan).' In Word Formation in South American Languages, edited by Swintha Danielsen, Katja Hannss, and Fernando Zúñiga, 113-42. Amsterdam, Philadelphia: John Benjamins. 